\title{
Swyer syndrome with dysgerminomas: ambiguity of pathologic diagnosis
} Zespół Swyera z obecnością rozrodczaka: niejednoznaczne rozpoznanie patologiczne

Department of Obstetrics and Gynecology, Dong-A University, College of Medicine, 26, Daesingongwon-ro, Seo-gu, Busan, 49201, Republic of Korea Correspondence: Jung-Woo Park, MD, PhD, Department of Obstetrics and Gynecology, Dong-A University, College of Medicine, 26, Daesingongwon-ro, Se0-gu, Busan, 49201, Republic of Korea, tel.: +8251240 5090, fax: +8252244 9553, e-mail: obgypjw@dau.ac.kr

Abstract Swyer syndrome - or pure gonadal dysgenesis - is one of the type of gonadal dysgenesis. The affected person suffers from primary amenorrhea, does not develop secondary sex characteristics. Seventeen-year-old girl was admitted due to right ovarian tumors of small cell carcinoma. Dysgerminoma shares several clinical and pathologic entities with small cell carcinoma. We reported a case of dysgerminoma in Swyer syndrome with pathologic ambiguity.

Keywords: Swyer syndrome, dysgerminoma, immunohistochemistry

Streszczenie Zespół Swyera - lub czysta dysgenezja gonad - jest jednym z rodzajów dysgenezji gonad. Osoba z zespołem Swyera cierpi na pierwotny brak miesiączki i nie rozwija wtórnych cech płciowych. Siedemnastoletnia dziewczynka została przyjęta z powodu drobnokomórkowego raka jajnika prawego. Rozrodczak - dysgerminoma - ma kilka cech klinicznych i patologicznych wspólnych z drobnokomórkowym rakiem jajnika. W pracy przedstawiono przypadek rozrodczaka w zespole Swyera $\mathrm{z}$ niejednoznacznym wynikiem badania histopatologicznego.

Słowa kluczowe: zespół Swyera, dysgerminoma, immunohistochemia 


\section{INTRODUCTION}

G onadal dysgenesis is a sex reversal disease, and is related to impaired gonadal development. Swyer syndrome or pure gonadal dysgenesis is a type of gonadal dysgenesis. In 1955, Swyer described the features of a normal female phenotype, primary amenorrhea, and 46/XY karyotype in Swyer syndrome for the first time ${ }^{(1,2)}$. It is also characterized by a hypoplastic uterus, normal vagina, and streak gonads instead of ovaries. An affected individual has primary amenorrhea and does not develop secondary sex characteristics ${ }^{(3)}$.

If there are no abnormal findings associated with the phenotype, the condition often remains undiagnosed until late adolescence. The condition is usually diagnosed during evaluations of primary amenorrhea or upon the discovery of a gonadal mass with symptoms of abdominal pain and discomfort. The estimated incidence of the syndrome is $1: 80,000-1: 100,000$. Of all cases, $10-20 \%$ are caused by loss-of-function mutations in the $S R Y$ gene present on the Y-chromosome ${ }^{(4)}$. Tumor development has been reported in $20-30 \%$ of Swyer syndrome cases. Gonadoblastoma is the most common type of the tumor. However, approximately $5 \%$ of dysgerminoma cases are also observed in patients with 46/XY Swyer syndrome ${ }^{(2)}$.

In the present case of dysgerminoma, there were tumors that required pathologic differential diagnosis. We report a rare case of suspected Swyer syndrome that exhibited pathological ambiguity.

\section{CASE PRESENTATION}

In November 2017, a 17-year-old woman was admitted to the Obstetrics and Gynecology Department in a hospital due to primary amenorrhea. A right ovarian mass measuring $4.5 \times 5.0 \times 6.0 \mathrm{~cm}$ was found on ultrasound imaging. The mass exhibited a heterogeneous mixed echogenicity. Laparoscopic exploration was performed, and the patient underwent right salpingo-oophorectomy during the surgery. The result of the biopsy confirmed ovarian small cell carcinoma with undifferentiated type and oviduct metastasis. The patient visited the Pediatric Department in our hospital for further evaluation of known ovarian cancer. Initial laboratory investigations showed a cancer antigen 125 level of $20 \mathrm{U} / \mathrm{mL}$, ROMA (risk of malignancy algorithm) value indicating low risk, carbohydrate antigen 19-9 of $15 \mathrm{U} / \mathrm{mL}$, carcinoembryonic antigen level of $0.803 \mathrm{ng} / \mathrm{mL}$, lactate dehydrogenase level of $485 \mathrm{U} / \mathrm{L}$, and alpha-fetoprotein (AFP) level increased to $1149 \mathrm{ng} / \mathrm{mL}$. The prolactin level was 19.8 (normal range, $8-29 \mathrm{mg} / \mathrm{mL}$ ). In addition, the patient did not have any history of headache, disturbance of vision, or anosmia. No abnormal findings were observed on positron emission tomography/computed tomography or hematological oncologic examination (i.e. peripheral blood smear and bone marrow biopsy)
While waiting for the results of the chromosome analysis, a germ cell tumor (GCT) was suspected due to the elevated AFP levels, and the pathologic examination of microscopic slides of the left ovarian mass was reassigned to the pathology department. The pathologic diagnosis was revised to dysgerminoma. On microscopic histopathologic examination, the tumor was composed of diffuse sheets of tumor cells interrupted by the fibrous septa, which were infiltrated by lymphocytes. The tumor cells were large and round in shape with a distinct cell membrane, clear cytoplasm and prominent nucleoli (Fig. $1 \mathrm{~A}$ ). On immunohistochemistry (IHC), the tumor cells were diffuse; the cytoplasmic membrane tested positive for c-kit and D2-40 (podoplanin), while it tested negative for glypican 3 and cluster of differentiation 30 (Fig. 1 B, C). After the revised diagnosis was made, the patient received four $\mathrm{cy}$ cles of combination chemotherapy of BEP regimen containing bleomycin, etoposide, and cisplatin. The result of chromosome analysis was $46 / \mathrm{XY}$, and the patient was referred to the Obstetrics and Gynecologic Department for surgical treatment.

Based on the history of gonadal dysgerminoma, genetic and imaging tests, as well as laboratory findings, Swyer syndrome was suspected. Considering the possibility of tumor development in the gonads, we decided to remove the remaining left gonad. Intraoperatively, a streak gonad on the left side was observed. The patient underwent laparoscopic left gonadectomy. There were no peritoneal or omental nodules or deposits. Pathological examination of the left gonad was performed. Grossly, the left gonad measured $2.3 \times 1.1 \mathrm{~cm}$ and had a grayish-brown fibrotic mass-like appearance on the cut section. The salpinx measured $4.7 \mathrm{~cm}$ in length and appeared like an otherwise normal salpinx. Microscopic examination of the left gonad showed nests composed of sex cord-like cells distributed around hyalinized acini (Fig. 2). The final diagnosis of the left gonad was gonadoblastoma. The postoperative course was without complications.

\section{DISCUSSION}

Early diagnosis of Swyer syndrome with 46/XY type is difficult because it is an extremely rare disease with various clinical presentations. Of these, the propensity of tumor development has been reported to be $20-30 \%{ }^{(2)}$. The most common ovarian tumor in the syndrome is gonadoblastoma, and dysgerminoma is found in about $5 \%$ of the cases ${ }^{(2)}$. Several studies have demonstrated a relationship between tumor risk and specific genes in Swyer syndrome. Dimitri et al. showed that a deletion or a mutation of the SRY gene is found in $20 \%$ of Swyer syndrome cases $^{(5)}$. Zhu et al. hypothesized that the expression of the Y chromosome would further increase the risk of developing gonadal tumors, such as dysgerminoma and gonadoblastoma. They also reported that $S R Y$ gene abnormalities found in gonadal tumors accounted for $50 \%$ 

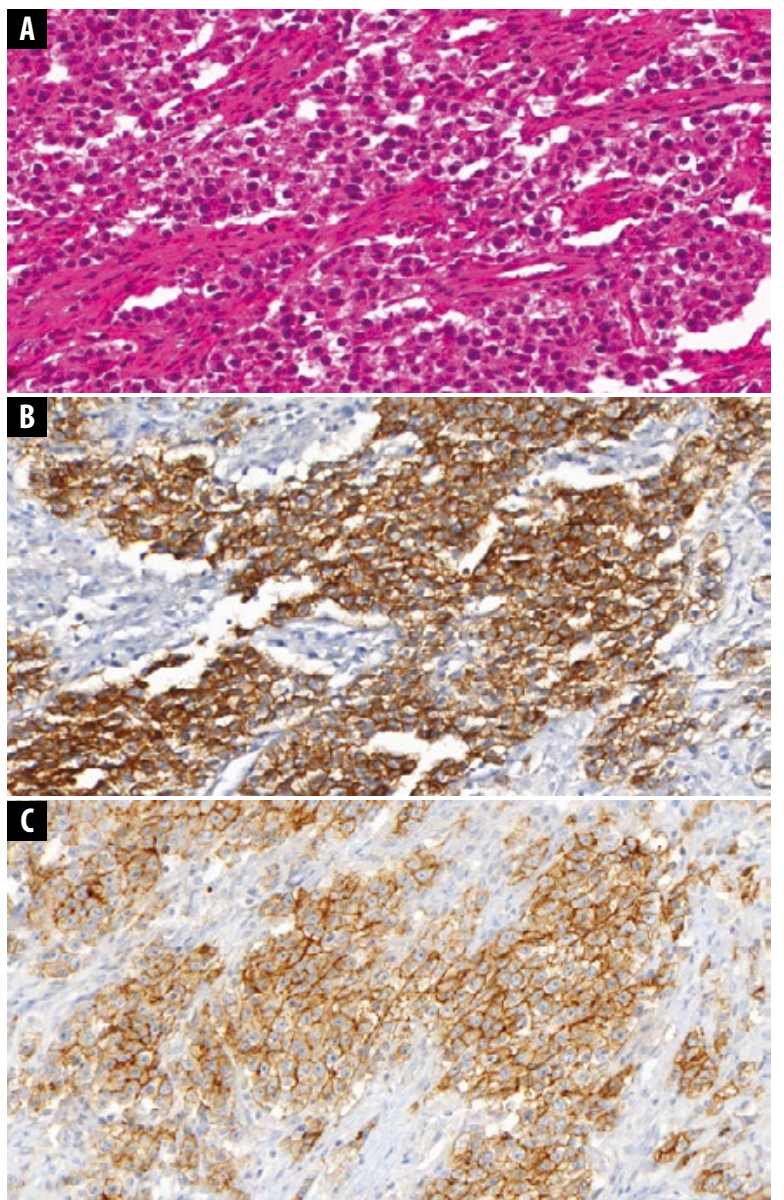

Fig. 1. Dysgerminoma. A. Sheets or nests of polygonal tumor cells are separated by fibrous septa with lymphocytic infiltration. The tumor cells have central large nuclei and abundant clear cytoplasm with distinctive cytoplasmic membranes (hematoxylin and eosin staining, $\times 40$ ). B, C. The tumor cells show diffuse cytoplasmic membranous c-kit (B) and D2-40 (C) expression (immunohistochemistry for c-kit and D2-40, ×20)

of cases ${ }^{(6)}$. Another study suggested that $S R Y$ gene abnormalities may play a role in the formation of gonadal tumors, especially dysgerminoma in Swyer syndrome ${ }^{(7)}$. Dysgerminoma is the only germ cell malignancy with a significant rate $(15 \%)$ of bilaterality ${ }^{(1)}$. Survival rates of XY gonadal dysgenesis and dysgerminoma are similar to those of XX type with malignant ovarian germ cell tumors, and the survival rate in both groups is dependent on the tumor stage (stage 1 96.9\%; stage 2-4 53.9\%) ${ }^{(8)}$. Reports regarding these patients with long survival times are limited. Due the high risk of tumor development the principal treatment involves gonadectomy without delay. In patients whose contralateral gonad has been preserved, a tumor could develop in $5-10 \%$ of the retained gonad over the next two years ${ }^{(1)}$.

The gross appearances of small cell carcinoma and dysgerminoma are similar, and some microscopic features

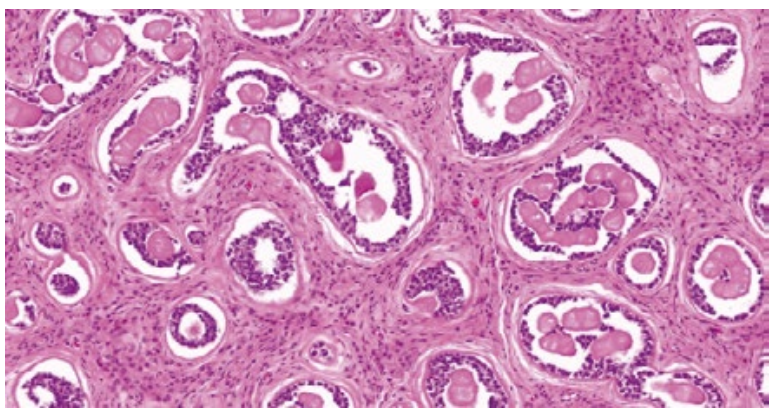

Fig. 2. Gonadoblastoma. The tumor shows nests composed of sex cord-like cells around hyalinized acini. However, a large germ cell population is not observed (hematoxylin and eosin staining, $\times 20$ )

are also shared. Small cell carcinoma has small, closely packed round cells with scant cytoplasm and hyperchromatic nuclei. The cytoplasm is composed of a folliclelike structure and is filled with eosinophilic fluid. Some dysgerminomas may show similar follicle-like space and small shrunken-type cells. Most dysgerminoma cells are large cells with a moderate to high nucleus-to-cytoplasm ratio, but large cell variants are present in about $50 \%$ of small cell carcinomas, which show abundant eosinophilic cytoplasm. Mitotic figures also frequently appear in both cell types. Of course, the follicle-like space is more common in small cell carcinomas, and this type of carcinoma may present with an eosinophilic cytoplasm of a rhabdoid appearance distinct from that in eosinophilic cells of dysgerminoma. However, differential diagnosis is still difficult to obtain with definite pathologic evidence $^{(9-11)}$. In order to add credibility to the ambiguity of the aforementioned pathologic diagnosis, IHC examinations targeting dysgerminoma and small cell carcinoma are recommended ${ }^{(9)}$. This is a case in which the diagnosis of dysgerminoma could be defined based on IHC, and a good example in which non-small cell carcinoma and embryonal carcinoma could be excluded based on IHC. D2-40 and c-kit have been identified as diagnostic markers of ovarian germ cell tumors ${ }^{(12)}$.

In the present case, gonadoblastoma was diagnosed during the second surgery. However, large germ cells, which are usually present in gonadoblastoma, were not noted. IHC for c-kit to reveal the germ cell population also showed negativity. This absence of the germ cell population was probably due to preoperative chemotherapy because germ cells are sensitive to chemotherapeutic agents. Although the germ cell populations were absent, this tumor was regarded as gonadoblastoma.

In summary, we report a case of dysgerminoma in Swyer syndrome with pathologic ambiguity. We also suggest that small cell carcinoma should be considered as a pathologically differential diagnosis of dysgerminoma.

\section{Conflict of interest}

No potential conflict of interest relevant to this article was reported. 


\section{References}

1. Berek JS, Hacker NF: Chapter 23. In: Bhasker K (ed.): Clinical Gynecology. $4^{\text {th }}$ ed., Elsevier, 2004: 514-518.

2. Speroff L, Frith MA: Clinical Gynecologic Endocrinology and Infertility. $7^{\text {th }}$ ed., Lippincott Williams \& Wilkins, Philadelphia 2005: 322-325, 348-349, 386-387.

3. Jones HW, Jones GS: Novak's Textbook of Gynecology. $10^{\text {th }}$ ed., Lippincott Williams \& Wilkins, Baltimore 1981: 112.

4. Hughes IA, Houk C, Ahmed SF et al.: Lawson Wilkins Pediatric Endocrine Society/European Society for Paediatric Endocrinology Consensus Group: Consensus statement on management of intersex disorders. J Pediatr Urol 2006; 2: 148-162.

5. Dimitri P, Cohen M, Wright $\mathrm{N}$ : Indications for familial screening and gonadectomy in patients with $46, \mathrm{XY}$ gonadal dysgenesis. Int J Gynaecol Obstet 2006; 95: 167-168.

6. Zhu J, Liu X, Jin $\mathrm{H}$ et al.: Swyer syndrome, 46 , XY gonadal dysgenesis, a sex reversal disorder with dysgerminoma: a case report and literature review. Clin Exp Obstet Gynecol 2011; 38: 414-418.
7. Uehara S, Funato T, Yaegashi $\mathrm{N}$ et al.: SRY mutation and tumor formation on the gonads of XP pure gonadal dysgenesis patients. Cancer Genet Cytogenet 1999; 113: 78-84.

8. Lin KY, Bryant S, Miller DS et al.: Malignant ovarian germ cell tumor - role of surgical staging and gonadal dysgenesis. Gynecol Oncol 2014; 134: 84-89.

9. Young RH: Ovarian tumors and tumor-like lesions in the first three decades. Semin Diagn Pathol 2014; 31: 382-426.

10. Pernick N: Small cell carcinoma of ovary, hypercalcemic type. PathologyOutlines.com, 2019. Available from: http://www. pathologyoutlines.com/topic/ovarytumorsmallcellhyper.html.

11. Song S, Reyes MC: Dysgerminoma. PathologyOutlines.com, 2019. Available from: http://www.pathologyoutlines.com/topic/ ovarytumordysgerminoma.html.

12. Chang MC, Vargas SO, Hornick JL et al.: Embryonic stem cell transcription factors and D2-40 (podoplanin) as diagnostic immunohistochemical markers in ovarian germ cell tumors. Int J Gynecol Pathol 2009; 28: 347-355. 